

\section{DISCLAIMER}

This report was prepared as an account of work sponsored by an agency of the United States Government. Neither the United States Government nor any agency Thereof, nor any of their employees, makes any warranty, express or implied, or assumes any legal liability or responsibility for the accuracy, completeness, or usefulness of any information, apparatus, product, or process disclosed, or represents that its use would not infringe privately owned rights. Reference herein to any specific commercial product, process, or service by trade name, trademark, manufacturer, or otherwise does not necessarily constitute or imply its endorsement, recommendation, or favoring by the United States Government or any agency thereof. The views and opinions of authors expressed herein do not necessarily state or reflect those of the United States Government or any agency thereof. 


\section{DISCLAIMER}

Portions of this document may be illegible in electronic image products. Images are produced from the best available original document. 
Printed

August 10, 1987
RFP-4100

UC-4 CHEMISTRY

DOE/TIC-4500 (Rev. 73)

RFP -4100

$\mathrm{DE} 88 \quad 000710$

\title{
ACTINIDE REMOVAL FROM AQUEOUS SOLUTION WITH ACTIVATED MAGNETITE
}

\author{
Robert L. Kochen
}

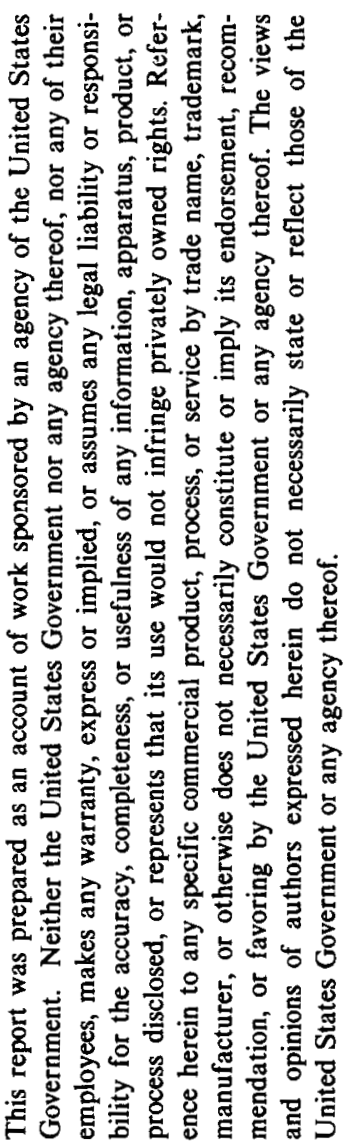

\section{SUBJECT DESCRIPTORS}

Activation

Americium

Magnetite

Plutonium

Waste Treatment

\footnotetext{
ROCKWELL INTERNATIONAL

NORTH AMERICAN SPACE OPERATIONS ROCKY FLATS PLANT P.O. BOX 464

GOLDEN, COLORADO 80402-0464
}

Prepared under Contract DE-AC04-76DPO3533

for the

Albuquerque Operations Office

U.S. Department of Energy 
RFP-4100

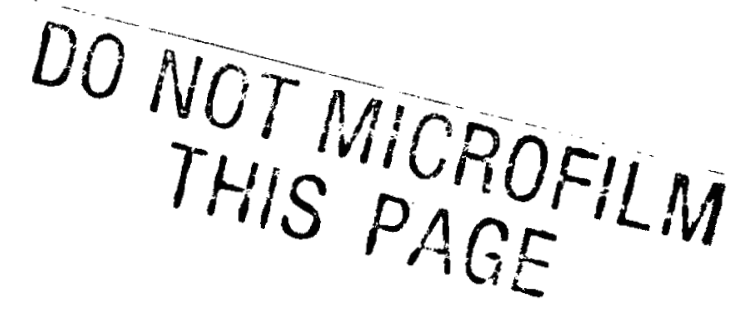

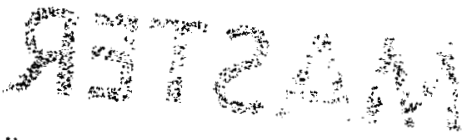




\section{CONTENTS}

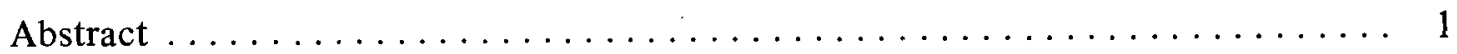

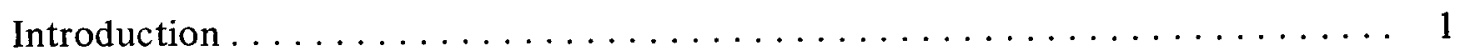

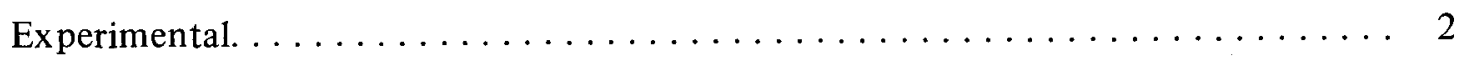

Commercial Magnetite Experiments $\ldots \ldots \ldots \ldots \ldots \ldots \ldots \ldots \ldots \ldots \ldots$

Wet and Dry Magnetite Experiments. ................. 2

Barium Hydroxide Experiments . . . . . . . . . . . . . . 4

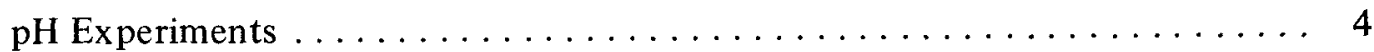

Magnetite Concentration Experiments $\ldots \ldots \ldots \ldots \ldots \ldots \ldots \ldots \ldots \ldots$

Analyses $\ldots \ldots \ldots \ldots \ldots \ldots \ldots \ldots \ldots \ldots \ldots \ldots \ldots \ldots \ldots \ldots$

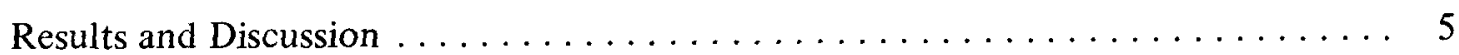

Commercial Magnetite Tests . . . . . . . . . . . . . . . 5

Wet and Dry Magnetite Tests. .................... 6

Barium Hydroxide Tests . . . . . . . . . . . . . . 7

pH Tests $\ldots \ldots \ldots \ldots \ldots \ldots \ldots \ldots \ldots \ldots \ldots \ldots \ldots \ldots$

Magnetite Concentration Tests . . . . . . . . . . . . . . . 8

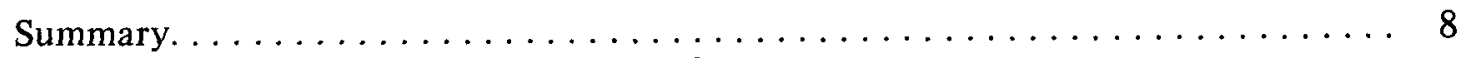

References. ........................... 11 


\section{A C K N O W E D G M E N}

The feature analyses performed by A. G. Grimes of Physical Metallurgy are greatly appreciated. Appreciation is also expressed to laboratory personnel at Rocky Flats for performing analyses. The ferrite program was funded by the Transuranic Waste Systems Office (TWSO). 


\title{
ACTINIDE REMOVAL FROM AQUEOUS SOLUTION
}

\section{WITH ACTIVATED MAGNETITE}

\author{
Robert L. Kochen
}

\begin{abstract}
An actinide aqueous waste treatment process using activated magnetite has been developed at Rocky Flats. The use and effectiveness of various magnetites in lowering actinide concentrations in aqueous solution are described. Experiments indicate that magnetite particle size and pretreatment (activation) of the magnetite surface with hydroxyl ions greatly influence the effective use of magnetite as an actinide adsorbent. With respect to actinide removal, $\mathrm{Ba}(\mathrm{OH})_{2}$-activated magnetite was more effective over a broader $\mathrm{pH}$ range than was $\mathrm{NaOH}$-activated magnetite. About $50 \%$ less $\mathrm{Ba}(\mathrm{OH})_{2}$-activated magnetite was required to lower plutonium concentration from $10^{-4}$ to $10^{-8} \mathrm{~g} / \ell$.
\end{abstract}

\section{INTRODUCTION}

The effectiveness of ferrite (magnetite) treatment for actinide removal from Rocky Flats aqueous process waste has been investigated and demonstrated successfully in the laboratory. These ferrite treatment techniques include batch methods ${ }^{1}$ as well as continuous methods in which ferrite is added in one or more treatment steps. ${ }^{2-4}$ Plutonium concentrations were consistently reduced from $10^{-4}$ to $10^{-8} \mathrm{~g} / \mathrm{l}$ or lower. Also, based on laboratory results, solid by-product waste generation was reduced by as much as $80 \%$ compared to existing plant operations employing hydroxide precipitation. The use of a ferrite process as an . alternative to the existing hydroxide precipitation process is attractive since it reduces reagent : handling.

With the preformed ferrite technique, iron ferrite $\left(\mathrm{FeO} \cdot \mathrm{Fe}_{2} \mathrm{O}_{3}\right.$ ) is prepared by adding sodium hydroxide solution to a solution of ferrous sulfate and ferric sulfate. The resulting ferrite slurry is then added to the process aqueous waste to effect actinide removal. This method required 5.0 parts reagent to produce 1.0 part ferrite with the remainder being 2.4 parts sodium sulfate and 1.6 parts water. ${ }^{3}$ The sodium sulfate was ultimately discharged as low-level salt waste, and the water was evaporated. Also, the solubility of sodium sulfate limits the concentration of ferrite slurries that can be prepared.

Other possibilities for improving the preformed ferrite addition technique also were investigated. One of these involves the synthesis of ferrite using air oxidation of ferrous hydroxide slurries under various conditions. ${ }^{5}$ Ferrite formed by the oxidative technique was comparable to preformed ferrite in removing actinides from waste solutions. However, ferrite formed by this method still requires preparing ferrous hydroxide slurries from ferrous sulfate and sodium hydroxide reagents. Also, reaction time for ferrite formation varies with volume and depth of slurry as well as contact time between air and slurry. Overall, this method requires 4.7 parts reagent $(0.07$ part oxygen included) to produce 1.0 part ferrite with the remainder being 1.8 parts sodium sulfate and 1.9 parts water. Again, the sodium sulfate would ultimately be discharged as low-level salt waste.

Another method involves the use of commercially available ferrite (magnetite) that has been activated with either sodium hydroxide ${ }^{6}$ or barium hydroxide. Activated commercial magnetite offers a more simplified waste treatment method compared with the preparation of preformed ferrite. Also, there are no by-products generated (e.g., sodium sulfate from the synthesis of preformed ferrite) that would eventually be discharged as low-level salt waste. In this study, four different sources of commercial magnetite are activated and evaluated for actinide removal from aqueous solutions. 


\section{EXPERIMENTAL}

\section{Commercial Magnetite Experiments}

Several parameters were varied to examine the effects on actinide removal from aqueous solution with commercial magnetite. These parameters involved the use of four magnetites, wet and dry magnetite, distilled and process water, two activating agents, $\mathrm{pH}$, and magnetite concentration. The magnetites were: Type BK-5599 from Pfizer, Inc., a technical grade magnetite from SargentWelch, a purified magnetite from Fisher Scientific, and a refined magnetite ore from Eriez Magnetics of Erie, Pennsylvania.

All actinide solutions consisted of plutonium nitrate $\left[\mathrm{Pu}\left(\mathrm{NO}_{3}\right)_{4}\right]$ and americium chloride $\left(\mathrm{AmCl}_{3}\right)$. Sodium hydroxide $(\mathrm{NaOH})$ was used to adjust actinide $\mathrm{pH}$ values. Unless otherwise noted, distilled water and reagent-grade chemicals were used in the experiments. Process water is defined as treated domestic water that has passed through a Backflow Preventer. All of the experiments were done in a $250-\mathrm{m} \ell$ beaker at ambient temperature with stirring rates of $200 \mathrm{rpm}$.

Four groups of actinide removal experiments were conducted with the four commercial magnetites. In the first group, each of the four magnetites $(0.1$ $\mathrm{g}$ each) was equilibrated with $13 \mathrm{~m} \ell$ of $0.02 \mathrm{M}$ barium hydroxide $\left[\mathrm{Ba}(\mathrm{OH})_{2} \cdot 8 \mathrm{H}_{2} \mathrm{O}\right]$ (prepared in both distilled and process water, $\mathrm{pH} 12.7)$ by stirring (200 rpm) for ten minutes at ambient temperature. The second and third group of experiments were handled in a similar manner, except each of the four magnetites $(0.1 \mathrm{~g}$ each) was equilibrated with $13 \mathrm{~m} \ell$ of $0.05 M \mathrm{NaOH}(\mathrm{pH} 12.7)$ prepared with both distilled and process water. In the fourth group of experiments, the four magnetites $(0.1 \mathrm{~g}$ each) were equilibrated 24 hours with $13 \mathrm{~m} \ell$ of $0.05 M \mathrm{NaOH}(\mathrm{pH} 12.7)$ prepared with process water.

After equilibration, the solution from each magnetite solid was decanted. Next, a $50-\mathrm{m} \ell$ aliquot of actinide solution $\left(1.0 \times 10^{-4} \mathrm{~g} / \mathrm{\ell}\right.$ plutonium and $1.4 \times 10^{-6} \mathrm{~g} / \mathrm{l}$ americium) at $\mathrm{pH} 12.0$ was added to each equilibrated magnetite solid. These mix tures were stirred $(200 \mathrm{rpm})$ for ten mintues at ambient temperature.
All of the supernatant liquids were then decanted from the magnetite solids and passed at $10 \mathrm{~m} \ell / \mathrm{min}$ through a glass column $(2.0 \mathrm{~cm}$ i.d. by $25 \mathrm{~cm})$ packed with a $10-\mathrm{cm}$ plug of fine No. 431 stainless steel wool. During this procedure, the column was placed between the pole faces of an ANAC Model 3470 laboratory electromagnet (Figure 1), and a field strength of 2000 Gauss was applied.

After each experiment, the stainless steel filled glass column was cleaned for repeated use. This was done by back flushing the column with $20 \mathrm{~m} \ell$ of water. Next, the column was washed with $20 \mathrm{~m} \ell$ of concentrated $\mathrm{HNO}_{3}$, rinsed with $40 \mathrm{ml}$ of water, rinsed with $20 \mathrm{~m} \ell$ of $0.2 \mathrm{M} \mathrm{NaOH}$, and again rinsed with $20 \mathrm{~m} \ell$ of distilled water.

\section{Wet and Dry Magnetite Experiments}

Pfizer magnetite (BK-5599), in both wet and dry form, was evaluated for actinide removal from aqueous solution. The wet magnetite was prepared by adding $13 \mathrm{~m} \ell$ of $0.02 M$ barium hydroxide $(\mathrm{pH}$ $12.7), 13 \mathrm{~m} \ell$ of $1 \times 10^{-6} \mathrm{M}$ sodium hydroxide $(\mathrm{pH}$

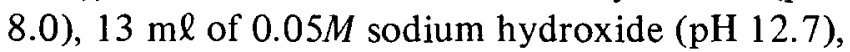
and $13 \mathrm{~m} \ell$ of actinide solution $\left(1.0 \times 10^{-4} \mathrm{~g} / \ell\right.$ plutonium and $1.4 \times 10^{-6} \mathrm{~g} / \mathrm{l}$ americium) at $\mathrm{pH}$ $12.7(\mathrm{NaOH})$ to dry magnetite samples $(0.1 \mathrm{~g}$ each $)$. Process water was used to prepare the solutions. Each of these samples was then equilibrated by stirring $(200 \mathrm{rpm})$ for ten minutes at ambient temperature.

After equilibration, the solution from each magnetite solid was decanted. Next, a 50-m $\ell$ aliquot of actinide solution $\left(1.0 \times 10^{-4} \mathrm{~g} / \ell\right.$ plutonium and $1.4 \times 10^{-6} \mathrm{~g} / \mathrm{l}$ americium) at $\mathrm{pH}$ 12.0 was added to each wet, equilibrated magnetite solid. A similar $50-\mathrm{m} \ell$ aliquot of the actinide solution was also added to a dry BK-5599 sample $(0.1 \mathrm{~g})$.

These mix tures were then stirred $(200 \mathrm{rpm})$ for ten minutes at ambient temperature. All of the supernatant liquids were then decanted from the magnetite solids and passed through the glass column described previously. 
FIGURE 1. Magnetic Separation Apparatus

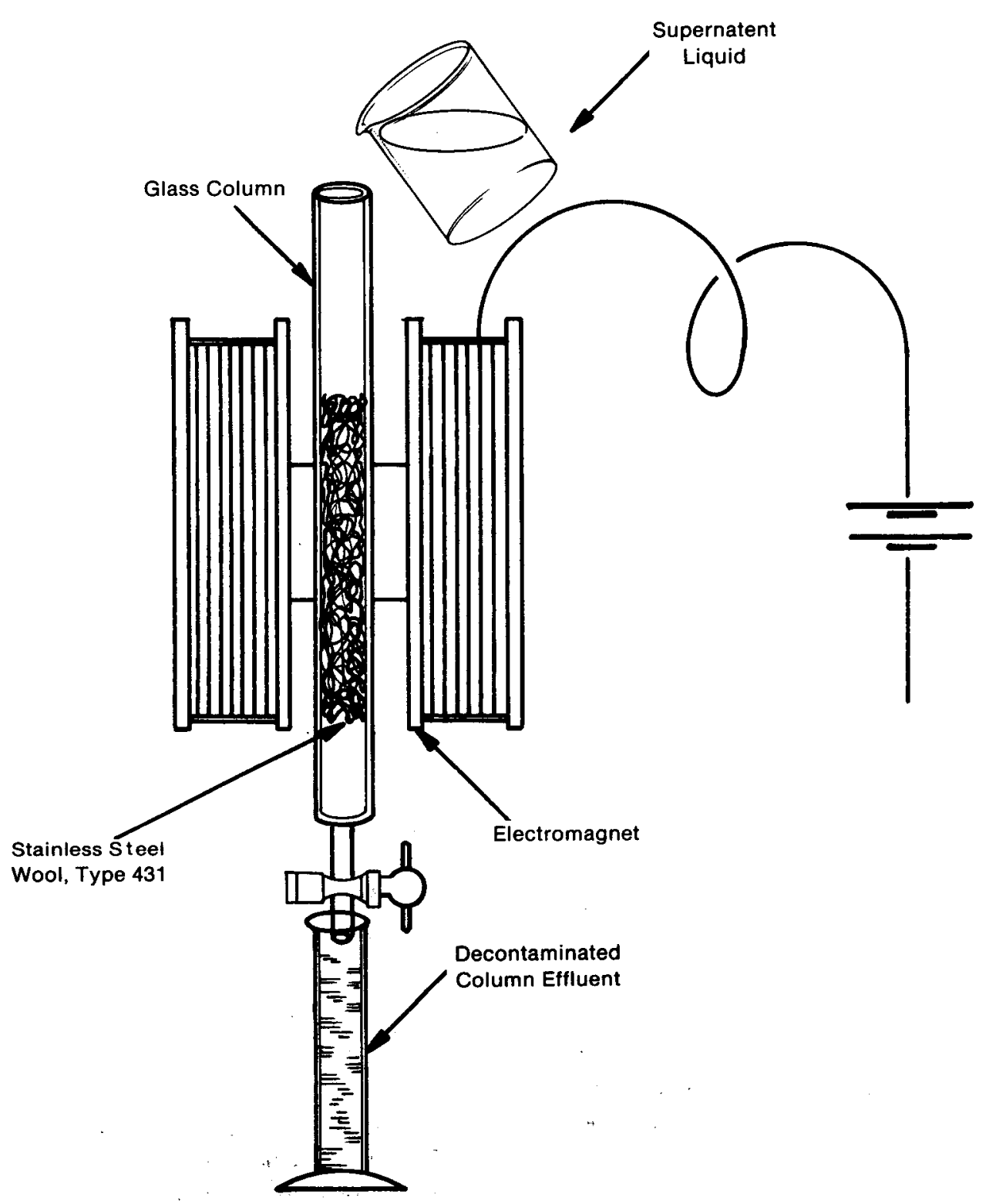




\section{Barium Hydroxide Experiments}

Six samples of Pfizer magnetite (BK-5599) were conditioned with six different concentrations of barium hydroxide solution. This was done by adding $13 \mathrm{~m} \ell$ of $0.0075,0.01,0.0125,0.015$, 0.02 , and 0.05 molar barium hydroxide (prepared with distilled water) to six $0.1-\mathrm{g}$ samples of the magnetite. Each of these samples was then equilibrated by gentle stirring $(200 \mathrm{rpm})$ for ten minutes at ambient temperature.

After equilibration, the solution from each magnetite solid was decanted. Next, a 50-m $\ell$ aliquot of actinide solution $\left(1.0 \times 10^{-4} \mathrm{~g} / \mathrm{l}\right.$ plutonium and $1.4 \times 10^{-6} \mathrm{~g} / \mathrm{l}$ americium) at $\mathrm{pH} 12.0$ was added to each equilibrated magnetite solid. Again, these mix tures were stirred $(200 \mathrm{rpm})$ for ten minutes at ambient temperature. All of the supernatant liquids were then decanted from the magnetite solids and passed through the glass column described previously.

\section{pH Experiments}

Three groups of experiments were conducted with Pfizer magnetite (BK-5599) to remove plutonium and americium from aqueous solutions at various $\mathrm{pH}$ values. The $\mathrm{pH}$ values of the actinide solutions were $11.0,11.5,12.0,12.5,13.0$, and 13.5.

In the first group of experiments, six magnetite samples $(0.1 \mathrm{~g}$ each) were equilibrated with $13 \mathrm{ml}$ of $0.02 M$ barium hydroxide solution ( $\mathrm{pH} 12.7)$ by stirring $(200 \mathrm{rpm})$ for ten minutes at ambient temperature. Similarly, groups two and three (six 0.1 -g samples per group) were equilibrated with $13 \mathrm{~m} \ell$ of $1.0 \times 10^{-6} \mathrm{M} \mathrm{NaOH}$ solution $(\mathrm{pH} \mathrm{8.0)}$

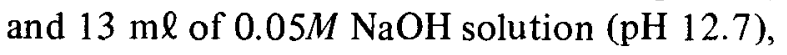
respectively. In all three cases, the solutions were prepared with process water.

After equilibration, the solution from each magnetite solid was decanted. Next, six 50-m $\ell$ aliquots of actinide solution $\left(1.0 \times 10^{-4} \mathrm{~g} / \ell\right.$ plutonium and $1.4 \times 10^{-6} \mathrm{~g} / \mathrm{l}$ americium), with $\mathrm{pH}$ values of $11.0,11.5,12.0,12.5,13.0$, and 13.5, were added to each group of the equilibrated magnetite solids. Again, these mixtures were stirred
(200 rpm) for ten minutes at ambient temperature. All of the supernatant liquids were then decanted from the magnetite solids and passed through the glass column as described previously.

\section{Magnetite Concentration Experiments}

Three groups of experiments were conducted to evaluate plutonium and americium removal with various amounts of Pfizer magnetite (BK-5599). The amounts of magnetite for each of the three groups (seven samples per group) were 0.01, 0.025, $0.05,0.075,0.1,0.125$, and $0.15 \mathrm{~g}$.

In the first group, each of the seven samples was equilibrated with $13 \mathrm{~m} \ell$ of $0.02 M$ barium hydroxide ( $\mathrm{pH} 12.7)$ in process water by stirring $(200 \mathrm{rpm})$ for ten minutes at ambient temperature. Similarly, each sample in the second group was equilibrated with $13 \mathrm{ml}$ of $0.05 \mathrm{M} \mathrm{NaOH}$ in process water $(\mathrm{pH} 12.7)$. A third group of seven samples was also equilibrated with $13 \mathrm{ml}$ of $0.05 \mathrm{M} \mathrm{NaOH}$ (process water). However, the equilibration time for these samples was extended to 24 hours.

After equilibration, the solution from each magnetite solid was decanted. A $50-\mathrm{m} \ell$ aliquot of actinide solution $\left(1.0 \times 10^{-4} \mathrm{~g} / \mathrm{\ell}\right.$ plutonium and $1.4 \times 10^{-6} \mathrm{~g} / \ell$ americium $)$ at $\mathrm{pH} 12.0$ was then added to each equilibrated magnetite solid. These mix tures were then stirred $(200 \mathrm{rpm})$ for ten minutes at ambient temperature. All of the supernatant liquids were then decanted from the magnetite solids and passed through a glass column as described previously.

\section{Analyses}

Samples of column effluent were analyzed for plutonium using a Nuclear Measurements Corporation PC-4 proportion alpha counter. Americium concentrations were determined using a Canberra Series 80 multichannel analyzer in conjunction with a Phoswich-type detector. All of the magnetite experiments were done in duplicate and the experimental results generally agreed to within $\pm 10 \%$.

A feature analysis was done on each of the four commercial magnetites to determine their particle 
size (average diameter). This was done with a Tracor Northern 5700 Image Analyzer in conjunction with a 5200 Scanning Electron Microscope.

The distilled and process water analyses were determined by semiquantitative emission spectroscopy, atomic absorption, and ion chromatography.

\section{RESULTS AND DISCUSSION}

\section{Commercial Magnetite Tests}

Four commercial magnetites (Pfizer BK-5599, Sargent-Welch, Fisher, and Eriez) were each activated with barium hydroxide and sodium hydroxide in distilled and process water (all at pH 12.7). These magnetites were then compared with each other and evaluated for actinide removal from aqueous solution. Results show that the $\mathrm{Ba}(\mathrm{OH})_{2}$-activated magnetites were more effective in removing plutonium from aqueous solution than were the same $\mathrm{NaOH}$-activated magnetites. In all cases, the Pfizer magnetite removed about ten times more plutonium than did both the Sargent-Welch and Fisher magnetites. The Eriez magnetite was the least effective at removing plutonium from aqueous solution. However, the $\mathrm{Ba}(\mathrm{OH})_{2}$-activated Eriez magnetite removed about 50\% more plutonium than did the $\mathrm{NaOH}$-activated Eriez magnetite. There was no significant difference between the distilled and process waters [used to prepare $\mathrm{Ba}(\mathrm{OH})_{2}$ and $\mathrm{NaOH}$ solutions at $\mathrm{pH} 12.7]$ with respect to actinide removal. These results are shown in Table 1.

TABLE 1. Actinide Removal With Activated Commercial Magnetites

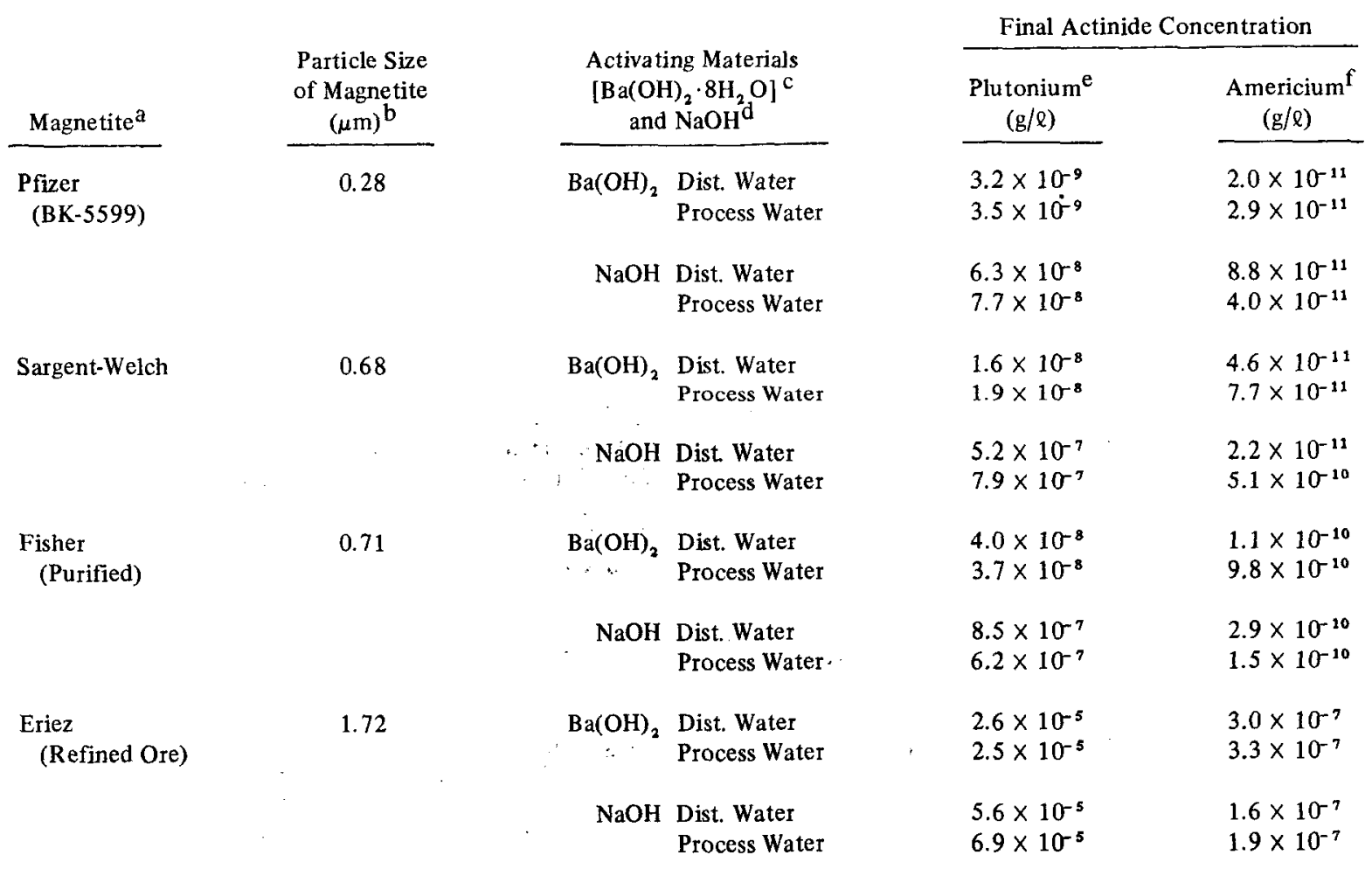

a. Two grams of magnetite per litre of actinide solution

b. Average diameter

c. $2.6 \mathrm{mmol} \mathrm{Ba}(\mathrm{OH})_{2} \cdot 8 \mathrm{H}_{2} \mathrm{O}$ per gram of magnetite for 10 minutes $(\mathrm{pH} 12.7$ )

d. $6.5 \mathrm{mmol} \mathrm{NaOH}$ per gram of magnetite for 10 minutes (pH 12.7)

e. Initial plutonium concentration: $1.0 \times 10^{-4} \mathrm{~g} / \mathrm{e}(\mathrm{pH} \mathrm{12.0)}$ in distilled water

f. Initial americium concentration: $1.4 \times 10^{-6} \mathrm{~g} / \ell(\mathrm{pH} 12.0)$ in distilled water 
The difference in each magnetite's ability to adsorb actinides from aqueous solution is attributed to the size of the particles comprising each magnetite. The smaller size magnetite particles have a greater surface area and, therefore, more adsorption capability.

A feature analysis was conducted on each of the four magnetites to determine their particle size (average diameter). These analyses showed that the average particle diameters for the Pfizer (BK-5599), Sargent-Welch, Fisher Scientific, and Eriez magnetites were $0.28,0.68,0.71$, and $1.72 \mu \mathrm{m}$, respectively. From this data, it is reasonable to conclude that the Pfizer (BK-5599) magnetite adsorbed more plutonium from solution because it had smaller size particles. The Sargent-Welch and Fisher magnetites responded similarly to actinide removal since both of these magnetites had similar size particles.

Since the NaOH-activated magnetites ( $\mathrm{pH} 12.7$ ) were less effective at removing actinides from solution, the equilibration time was increased from ten minutes to 24 hours. A small improvement in plutonium removal was observed with the longer equilibration period. These results are shown in Table 2. The analyses for the distilled and process waters used in this study are presented in Table 3.

\section{Wet and Dry Magnetite Tests}

The adsorption mechanism of metals from solution by magnetite is thought to occur through metal hydroxide species. ${ }^{7}$ In an alkaline solution, most metal ions form insoluble species and may complex with additional hydroxide ions. Magnetite strongly adsorbs hydroxide ions and metal ions bond to the magnetite surface through these hydroxide ions.

When dry magnetite is prewetted by an alkaline solution, it is more effective than dry magnetite for removing actinides from aqueous solution. For example, two grams of dry Pfizer (BK-5599) magnetite lowers the plutonium concentration in one litre of aqueous soltuion $(\mathrm{pH} \mathrm{12.0)}$ from $10^{-4}$ to $10^{-5} \mathrm{~g} / \ell$. If this same magnetite is first activated with $\mathrm{NaOH}$ solution ( $\mathrm{pH} 8.0$ to 12.7 ), the plutonium concentration is lowered from $10^{-4}$ to $10^{-8} \mathrm{~g} / \ell$. However, if there are actinide ions $\left(1.0 \times 10^{-4} \mathrm{~g} / \ell\right.$ plutonium and $1.4 \times 10^{-6} \mathrm{~g} / \ell$ americium) present during activation with the $\mathrm{NaOH}$ ( $\mathrm{pH} 12.7$ ), the plutonium concentration is lowered to only $10^{-5} \mathrm{~g} / \ell$.

TABLE 2. Comparison of Actinide Removal With 10-Minute and 24-Hour NaOH-Activated Commercial Magnetites

\begin{tabular}{|c|c|c|c|c|c|}
\hline \multirow[b]{2}{*}{ Magnetite $^{\mathrm{a}}$} & \multirow[b]{2}{*}{$\begin{array}{c}\text { Particle Size } \\
\text { of Magnetite } \\
(\mu \mathrm{m})^{b} \\
\end{array}$} & \multicolumn{2}{|c|}{ 10-Minute Equilibration } & \multicolumn{2}{|c|}{ 24-Hour Equilibration } \\
\hline & & $\begin{array}{c}\text { Final Plutonium } \\
\text { Concentration } \\
(\mathrm{g} / \mathrm{l})\end{array}$ & $\begin{array}{c}\text { Final Americium }{ }^{\mathrm{d}} \\
\text { Concentration } \\
(\mathrm{g} / \mathrm{l})\end{array}$ & $\begin{array}{c}\text { Final Plutonium }{ }^{c} \\
\text { Concentration } \\
(\mathrm{g} / \mathrm{l})\end{array}$ & $\begin{array}{c}\text { Final Americium } \\
\text { Concentration } \\
(\mathrm{g} / \mathrm{l})\end{array}$ \\
\hline $\begin{array}{l}\text { Pfizer } \\
\quad(\text { BK-5599) }\end{array}$ & 0.28 & $7.7 \times 10^{-8}$ & $4.0 \times 10^{-11}$ & $6.4 \times 10^{-8}$ & $7.0 \times 10^{-11}$ \\
\hline $\begin{array}{l}\text { Sargent-Welch } \\
\text { (Technical) }\end{array}$ & 0.68 & $7.9 \times 10^{-7}$ & $5.1 \times 10^{-10}$ & $7.0 \times 10^{-7}$ & $7.3 \times 10^{-10}$ \\
\hline $\begin{array}{l}\text { Fisher } \\
\quad \text { (Purified) }\end{array}$ & 0.71 & $6.2 \times 10^{-7}$ & $1.5 \times 10^{-10}$ & $1.8 \times 10^{-7}$ & $1.5 \times 10^{-10}$ \\
\hline $\begin{array}{l}\text { Eriez } \\
\quad \text { (Refined Ore) }\end{array}$ & 1.72 & $6.0 \times 10^{-5}$ & $1.9 \times 10^{-7}$ & $5.1 \times 10^{-5}$ & $1.0 \times 10^{-7}$ \\
\hline $\begin{array}{l}\text { a. Equilibrated v } \\
\text { Two grams of } \\
\text { b. Average diam } \\
\text { c. Initial plutoni } \\
\text { d. Initial americi }\end{array}$ & $\begin{array}{l}\mathrm{mmol} \mathrm{NaOH} \\
\text { tite per litre o } \\
\text { centration: } 1 \\
\text { centration: } 1\end{array}$ & $\begin{array}{l}\text { of magnetite in } \mathrm{p} \\
\text { e solution. } \\
{ }^{4} \mathrm{~g} / \mathrm{Q}(\mathrm{pH} 12.0) \\
\mathrm{g} / \mathrm{Q}(\mathrm{pH} 12.0)\end{array}$ & water (pH 12.7). & & \\
\hline
\end{tabular}


TABLE 3. Water Analyses

\begin{tabular}{|c|c|c|}
\hline Element ${ }^{a}$ & $\begin{array}{l}\text { Distilled Water } \\
\quad(\mathrm{ppm})\end{array}$ & $\begin{array}{c}\text { Process Water } \\
\text { (ppm) }\end{array}$ \\
\hline Al & $<1.0$ & $<1.0$ \\
\hline$A \mathbf{s}^{\mathrm{b}}$ & $<0.01$ & $<0.01$ \\
\hline B & $<5.0$ & $<5.0$ \\
\hline $\mathrm{Ba}^{\mathrm{b}}$ & $<1.0$ & $<1.0$ \\
\hline $\mathrm{Be}^{\mathrm{b}}$ & $<0.05$ & $<0.05$ \\
\hline $\mathrm{Ca}^{\mathrm{b}}$ & 6.9 & 5.1 \\
\hline $\mathrm{Cd}^{\mathrm{b}}$ & $<0.01$ & $<0.01$ \\
\hline $\mathrm{Co}$ & $<0.001$ & $<0.001$ \\
\hline $\mathrm{Cr}^{\mathrm{b}}$ & $<0.05$ & $<0.05$ \\
\hline $\mathrm{Cu}$ & $<1.0$ & $<1.0$ \\
\hline $\mathrm{Fe}$ & $<1.0$ & $<1.0$ \\
\hline $\mathrm{Hg}^{\mathrm{b}}$ & $<0.002$ & $<0.002$ \\
\hline $\mathbf{K}^{\mathbf{b}}$ & 0.6 & 0.1 \\
\hline $\mathbf{L i}$ & $<1.0$ & $<1.0$ \\
\hline $\mathrm{Mg}^{\mathrm{b}}$ & 1.9 & 0.3 \\
\hline $\mathrm{Mn}$ & $<0.0001$ & 0.0001 \\
\hline Mo & $<0.0002$ & 0.0035 \\
\hline $\mathrm{Na}^{\mathrm{b}}$ & 5.6 & 0.1 \\
\hline $\mathrm{Ni}$ & $<0.0021$ & 0.0044 \\
\hline $\mathrm{Pb}$ & $<0.0001$ & 0.0009 \\
\hline $\mathrm{Se}$ & $<0.01$ & $<0.01$ \\
\hline $\mathrm{Si}^{\mathrm{b}}$ & $<0.01$ & 0.4 \\
\hline Sn & $<0.0004$ & $<0.0004$ \\
\hline $\mathrm{v}$ & $<0.0004$ & $<0.0004$ \\
\hline $\mathrm{Zn}$ & $<0.0022$ & $<0.0022$ \\
\hline \multicolumn{3}{|l|}{ Analysis $^{\mathrm{c}}$} \\
\hline T.D.S. & 13 & 44 \\
\hline Hardness & 13.1 & 598 \\
\hline $\mathrm{Cl}^{-}$ & $<1.0$ & 1.9 \\
\hline$F^{-}$ & $<1.0$ & $<1.0$ \\
\hline $\mathrm{SO}_{4}^{-2}$ & 3.8 & 9.8 \\
\hline \multicolumn{3}{|c|}{$\begin{array}{l}\text { a. Determined by semiquantitative } \\
\text { emission spectroscopy unless otherwise noted. } \\
\text { b. Determined by atomic absorption. } \\
\text { c. Determined by ion chromatography. }\end{array}$} \\
\hline
\end{tabular}

A more effective activating agent for magnetite is. barium hydroxide solution. Pfizer (BK-5599) magnetite, when activated with $\mathrm{Ba}(\mathrm{OH})_{2}$ solution ( $\mathrm{pH}$ 12.7), lowers plutonium concentration from $10^{-4}$ to $10^{-9} \mathrm{~g} / \ell$.

Magnetite may have a greater affinity for barium hydroxide than it does for sodium hydroxide. If this is the case, there maybe a greater concentration of hydroxide ions available to import more negative charge to the magnetite surface. This would result in greater adsorption by the magnetite of cations such as plutonium and americium. The results for the wet and dry magnetite tests are presented in Table 4.

\section{Barium Hydroxide Tests}

Pfizer (BK-5599) magnetite was equilibrated with various concentrations of barium hydroxide solution. A quantity of barium hydroxide (for activation) was selected that would produce about a ten-fold increase in plutonium removal over the best sodium hydroxide activated magnetite. This quantity was about $2.6 \mathrm{mmol}$ barium hydroxide per gram of BK-5599 magnetite. The effect of magnetite on actinide removal as a function of barium hydroxide concentration is presented in Table 5.

TABLE 4. Actinide Removal With Wet and Dry Pfizer (BK-5599) Magnetite

\begin{tabular}{|c|c|c|c|}
\hline \multirow[b]{2}{*}{$\begin{array}{c}\text { BK-5599 } \\
(2 \mathrm{~g} / \ell)\end{array}$} & \multirow[b]{2}{*}{$\begin{array}{c}\text { Magnetite } \\
(\mathrm{pH})\end{array}$} & \multicolumn{2}{|c|}{ Final Actinide Concentration } \\
\hline & & $\begin{array}{l}\text { Plutonium } \mathrm{e} \\
(\mathrm{g} / \mathrm{e})\end{array}$ & $\begin{array}{c}\text { Americium }^{f} \\
(\mathrm{~g} / \mathrm{l})\end{array}$ \\
\hline Dry & - & $3.6 \times 10^{-5}$ & $7.9 \times 10^{-8}$ \\
\hline $\begin{array}{c}\mathrm{Wet}^{\mathrm{a}} \\
{[\mathrm{NaOH}, \mathrm{Pu}, \mathrm{Am}]}\end{array}$ & 12.7 & $4.6 \times 10^{-5}$ & $8.4 \times 10^{-8}$ \\
\hline $\begin{array}{c}\mathrm{Wet}^{\mathrm{b}} \\
{[\mathrm{NaOH}]}\end{array}$ & 8.0 & $1.1 \times 10^{-8}$ & $1.1 \times 10^{-11}$ \\
\hline $\begin{array}{c}\text { Wet }^{\mathrm{c}} \\
{[\mathrm{NaOH}]}\end{array}$ & 12.7 & $7.7 \times 10^{-8}$ & $4.0 \times 10^{-11}$ \\
\hline $\begin{array}{c}\text { Wet }^{d} \\
{\left[\mathrm{Ba}(\mathrm{OH})_{2}\right]}\end{array}$ & 12.7 & $3.5 \times 10^{-9}$ & $2.9 \times 10^{-11}$ \\
\hline
\end{tabular}

a. Equilibrated (10 minutes) with $6.5 \mathrm{mmol} \mathrm{NaOH}$, $5.4 \times 10^{-5} \mathrm{mmol}$ plutonium, and $7.6 \times 10^{-7} \mathrm{mmol}$ americium per gram of magnetite in process water.

b. Equilibrated (10 minutes) with $1.3 \times 10^{-4} \mathrm{mmol}$ $\mathrm{NaOH}$ per gram of magnetite in process water.

c. Equilibrated (10 minutes) with $6.5 \mathrm{mmol} \mathrm{NaOH}$ per gram of magnetite in process water.

d. Equilibrated (10 minutes) with $2.6 \mathrm{mmol}$ $\mathrm{Ba}(\mathrm{OH})_{2} \cdot 8 \mathrm{H}_{2} \mathrm{O}$ per gram of magnetite in process water.

e. Initial plutonium concentration: $1.0 \times 10^{-4} \mathrm{~g} / \mathrm{\ell}(\mathrm{pH} 12.0)$

f. Initial americium concentration: $1.4 \times 10^{-6} \mathrm{~g} / \mathrm{\ell}(\mathrm{pH} 12.0)$ 
TABLE 5. Effect of Pfizer (BK-5599) Magnetite on Actinide Removal as a Function of Barium Hydroxide Concentration

\begin{tabular}{|c|c|c|c|c|}
\hline \multirow{3}{*}{$\begin{array}{l}\text { BK-5599 } \\
\text { Magnetite } \\
\quad(\mathrm{g} / \ell)\end{array}$} & \multirow{2}{*}{\multicolumn{2}{|c|}{ Barium Hydroxide ${ }^{\mathrm{a}}$}} & \multicolumn{2}{|c|}{ Final Actinide Concentration } \\
\hline & & & \multirow{2}{*}{$\begin{array}{l}\text { Plutonium } \\
\quad(g / l)\end{array}$} & \multirow{2}{*}{$\begin{array}{c}\text { Americium } \\
\underset{(g / \ell)}{c}\end{array}$} \\
\hline & $(\mathrm{mmol})$ & $(\mathrm{pH})$ & & \\
\hline 2 & 2.0 & 12.2 & $2.3 \times 10^{-8}$ & $2.8 \times 10^{-10}$ \\
\hline 2 & 2.6 & 12.4 & $1.3 \times 10^{-8}$ & $8.9 \times 10^{-11}$ \\
\hline 2 & 3.2 & 12.5 & $7.2 \times 10^{-9}$ & $6.8 \times 10^{-11}$ \\
\hline 2 & 3.9 & 12.6 & $4.6 \times 10^{-9}$ & $4.4 \times 10^{-11}$ \\
\hline 2 & 5.2 & 12.7 & $3.2 \times 10^{-9}$ & $2.0 \times 10^{-11}$ \\
\hline 2 & 13.0 & 12.8 & $5.0 \times 10^{-10}$ & $3.2 \times 10^{-12}$ \\
\hline \multicolumn{5}{|c|}{$\begin{array}{l}\text { a. Solutions prepared with distilled water. } \\
\text { b. Initial plutonium concentration: } 1.0 \times 10^{-4} \mathrm{~g} / \mathrm{l}(\mathrm{pH} \mathrm{12.0)} \\
\text { c. Initial americium concentration: } 1.4 \times 10^{-6} \mathrm{~g} / \mathrm{l}(\mathrm{pH} 12.0)\end{array}$} \\
\hline
\end{tabular}

\section{pH Tests}

Results show that $\mathrm{NaOH}$-activated Pfizer (BK-5599) magnetite $(2 \mathrm{~g} / \ell)$ lowers plutonium concentrations from $10^{-4}$ to $10^{-8} \mathrm{~g} / \ell$ if the $\mathrm{pH}$ of the actinide solution is between 12.0 and 13.0. If this $\mathrm{pH}$ goes below 11.5 or approaches 13.5 , plutonium removal is substantially decreased. In contrast, $\mathrm{Ba}(\mathrm{OH})_{2}$ activated magnetite lowers plutonium concentrations from $10^{-4}$ to $10^{-8}$ and $10^{-9} \mathrm{~g} / \ell$ over the $\mathrm{pH}$ range of 11 through 13.5. These results are presented in Table 6.

\section{Magnetite Concentration Tests}

Various amounts of activated Pfizer (BK-5599) magnetite were evaluated for actinide removal from aqueous solution. Activation was accomplished by equilibrating this magnetite (ten minutes) with barium hydroxide in process water ( $\mathrm{pH} 12.7)$ as well as with sodium hydroxide in process water $(\mathrm{pH} 12.7)$. Results show that compared with the $\mathrm{NaOH}$-activated magnetite, about $50 \%$ less $\mathrm{Ba}(\mathrm{OH})_{2}$-activated magnetite was needed to lower the plutonium concentration from $10^{-4}$ to $10^{-8} \mathrm{~g} / \ell$. These results are shown in Table 7 .

Since the $\mathrm{NaOH}$-activated magnetites ( $\mathrm{pH}$ 12.7) were less effective in removing actinides from solution, the equilibration time was increased from ten minutes to 24 hours. A small improvement in plutonium removal occurred with the longer equilibration period. These results are shown in Table 8.

\section{SUMMARY}

In this study, four commercial magnetites were evaluated for actinide removal from aqueous solution. Two major factors appear to greatly influence the effective use of magnetite as an actinide adsorbent. One of these factors is magnetite particle size. (Smaller size particles mean greater surface area for more adsorption capability.) The Pfizer magnetite (BK-5599), with its smaller particle size, was at least ten times more effective at lowering plutonium concentrations than were the Sargent-Welch, Fisher Scientific, and Eriez magnetites.

A second factor that greatly influences the use of magnetite as an actinide adsorbent is pretreatment (activation) of the magnetite surface with hydroxyl ions. The $\mathrm{Ba}(\mathrm{OH})_{2}$-activated Pfizer magnetite (BK-5599) was effective over the $\mathrm{pH}$ range of 11.0 through 13.5 and lowered plutonium concentrations from $10^{-4}$ to $10^{-8}$ and $10^{-9} \mathrm{~g} / \ell$. This same $\mathrm{NaOH}$-activated magnetite lowered plutonium concentrations from $10^{-4}$ and $10^{-8} \mathrm{~g} / \ell$ at a $\mathrm{pH}$ between 12.0 and 13.0. Also, the presence of actinide ions during magnetite activation with hydroxyl ions greatly lowers the effectiveness of magnetite as an actinide adsorbent.

Compared to $\mathrm{NaOH}$-activated magnetite, about $50 \%$ less $\mathrm{Ba}(\mathrm{OH})$-activated magnetite was required to lower plutonium concentrations from $10^{-4}$ to $10^{-8}$ $\mathrm{g} / \ell$. Also, with respect to actinide removal, there was no significant difference between the distilled and process waters [used to prepare $\mathrm{Ba}(\mathrm{OH})_{2}$ and $\mathrm{NaOH}$ solutions for magnetite activation] .

The use of activated commercial magnetite as an alternative to using preformed ferrite for actinide waste management is attractive because fewer reagents are needed. Also, compared to preformed ferrite, there is no by-product (e.g., sodium sulfate) that would ultimately be discharged as low-level waste. 
TABLE 6. Effect of pH on Actinide Removal With Pfizer (BK-5599) Magnetite

BK-5599

Magnetite $^{\mathrm{a}}$ $(\mathrm{g} / \mathrm{l})$

2

2

2

2

2

2

2

2

2

2

2

2

\section{2}

2

2

2

2

2

\begin{tabular}{|c|c|}
\hline \multicolumn{2}{|c|}{ Activation $^{b}$} \\
\hline Material & $(\mathrm{pH})$ \\
\hline $\mathrm{Ba}(\mathrm{OH})_{2}$ & 12.7 \\
\hline $\mathrm{NaOH}$ & 12.7 \\
\hline $\mathrm{NaOH}$ & 8.0 \\
\hline
\end{tabular}

$\begin{array}{ll}\mathrm{Ba}(\mathrm{OH})_{2} & 12.7 \\ \mathrm{NaOH} & 12.7\end{array}$

$\mathrm{NaOH} \quad 8.0$

$\begin{array}{lr}\mathrm{Ba}(\mathrm{OH})_{2} & 12.7 \\ \mathrm{NaOH} & 12.7 \\ \mathrm{NaOH} & 8.0\end{array}$

$\mathrm{Ba}(\mathrm{OH})_{2} \quad 12.7$

$\mathrm{NaOH} \quad 12.7$

$\mathrm{NaOH} \quad 8.0$

$\begin{array}{lr}\mathrm{Ba}(\mathrm{OH})_{2} & 12.7 \\ \mathrm{NaOH} & 12.7 \\ \mathrm{NaOH} & 8.0\end{array}$

$\mathrm{Ba}(\mathrm{OH})_{2} \quad 12.7$

$\mathrm{NaOH} \quad 12.7$

$\mathrm{NaOH} \quad 8.0$
Final Actinide Concentration

\section{Actinide Solution}

$(\mathrm{pH})$

11.0

11.5

12.0

12.5

13.0

Plutonium $^{\mathrm{c}} \quad$ Americium $^{\mathrm{d}}$

(g/l)

$(\mathrm{g} / \mathrm{l})$

$1.8 \times 10^{-8}$

$1.8 \times 10^{-8}$
$1.7 \times 10^{-6}$

$4.8 \times 10^{-6}$

$8.1 \times 10^{-11}$

$3.3 \times 10^{-9}$

$9.2 \times 10^{-9}$

$2.9 \times 10^{-8}$

$1.2 \times 10^{-7}$

$4.6 \times 10^{-11}$

$2.0 \times 10^{-9}$

$5.1 \times 10^{-6} \quad 6.7 \times 10^{-9}$

$3.5 \times 10^{-9}$

$7.7 \times 10^{-8}$

$2.9 \times 10^{-11}$

$9.0 \times 10^{-11}$

$1.1 \times 10^{-8}$

$1.1 \times 10^{-11}$

$3.6 \times 10^{-9}$

$4.6 \times 10^{-8}$

$4.9 \times 10^{-11}$

$1.6 \times 10^{-8}$

$5.3 \times 10^{-11}$

$4.2 \times 10^{-11}$

$1.4 \times 10^{-9}$

$6.1 \times 10^{-8}$

$5.9 \times 10^{-11}$

$3.4 \times 10^{-8}$

$4.0 \times 10^{-11}$

13.5

$2.2 \times 10^{-9}$

$1.4 \times 10^{-5}$

$1.4 \times 10^{-7}$

$6.0 \times 10^{-11}$

$8.6 \times 10^{-8}$

$1.1 \times 10^{-10}$

a. Grams of magnetite per litre of actinide solution.

b. Ten minutes with solutions prepared in process water.

c. Initial plutonium concentration: $1.0 \times 10^{-4} \mathrm{~g} / \mathrm{\Omega}$

d. Initial americium concentration: $1.4 \times 10^{-6} \mathrm{~g} / \mathrm{\ell}$ 
TABLE 7. Actinide Removal as a Function of Magnetite Concentration

\begin{tabular}{|c|c|c|c|}
\hline \multirow{2}{*}{$\begin{array}{c}\text { BK-5599 } \\
\text { Magnetite } \\
\text { (g/l) }\end{array}$} & \multirow[b]{2}{*}{$\begin{array}{c}\text { Activation }{ }^{\mathrm{b}} \text { Materials } \\
\text { at } \mathrm{pH} 12.7\end{array}$} & \multicolumn{2}{|c|}{ Final Actinide Concentration } \\
\hline & & $\begin{array}{l}\text { Plutonium } \\
(\mathrm{g} / \mathrm{l})\end{array}$ & $\begin{array}{c}\text { Americium }^{d} \\
(\mathrm{~g} / \mathrm{\ell})\end{array}$ \\
\hline 0.2 & $\begin{array}{l}\mathrm{Ba}(\mathrm{OH})_{2} \\
\mathrm{NaOH}\end{array}$ & $\begin{array}{c}3.5 \times 10^{-7} \\
-\end{array}$ & $6.3 \times 10^{-11}$ \\
\hline 0.5 & $\begin{array}{l}\mathrm{Ba}(\mathrm{OH})_{2} \\
\mathrm{NaOH}\end{array}$ & $\begin{array}{l}1.1 \times 10^{-7} \\
1.6 \times 10^{-6}\end{array}$ & $\begin{array}{l}3.8 \times 10^{-11} \\
9.0 \times 10^{-11}\end{array}$ \\
\hline 1.0 & $\begin{array}{l}\mathrm{Ba}(\mathrm{OH})_{2} \\
\mathrm{NaOH}\end{array}$ & $\begin{array}{l}4.9 \times 10^{-8} \\
4.4 \times 10^{-7}\end{array}$ & $\begin{array}{l}3.0 \times 10^{-11} \\
4.6 \times 10^{-11}\end{array}$ \\
\hline 1.5 & $\begin{array}{l}\mathrm{Ba}(\mathrm{OH})_{2} \\
\mathrm{NaOH}\end{array}$ & $\begin{array}{l}9.8 \times 10^{-9} \\
3.4 \times 10^{-7}\end{array}$ & $\begin{array}{l}2.8 \times 10^{-11} \\
5.0 \times 10^{-11}\end{array}$ \\
\hline 2.0 & $\begin{array}{l}\mathrm{Ba}(\mathrm{OH})_{2} \\
\mathrm{NaOH}\end{array}$ & $\begin{array}{l}3.5 \times 10^{-9} \\
7.7 \times 10^{-8}\end{array}$ & $\begin{array}{l}2.9 \times 10^{-11} \\
4.0 \times 10^{-11}\end{array}$ \\
\hline 2.5 & $\begin{array}{l}\mathrm{Ba}(\mathrm{OH})_{2} \\
\mathrm{NaOH}\end{array}$ & $4.9 \times 10^{-8}$ & $3.8 \times 10^{-11}$ \\
\hline 3.0 & $\begin{array}{l}\mathrm{Ba}(\mathrm{OH})_{2} \\
\mathrm{NaOH}\end{array}$ & $2.8 \times 10^{-8}$ & $2.8 \times 10^{-11}$ \\
\hline
\end{tabular}

a. Grams of magnetite per litre of actinide solution.

b. Ten minutes with solutions prepared in process water.

c. Initial plutonium concentration: $1.0 \times 10^{-4} \mathrm{~g} / \mathrm{Q}(\mathrm{pH} 12.0)$

d. Initial americium concentration: $1.4 \times 10^{-6} \mathrm{~g} / \mathrm{\ell}(\mathrm{pH} 12.0)$

TABLE 8. Actinide Removal With $\mathrm{NaOH}$ Activated (24-Hours) Pfizer (BK-5599) Magnetite

\begin{tabular}{c}
$\begin{array}{c}\text { BK-5599 } \\
\text { Magnetite } \\
(\mathrm{g} / \mathrm{l})\end{array}$ \\
\hline 0.2 \\
0.5 \\
1.0 \\
1.5 \\
2.0 \\
2.5 \\
3.0
\end{tabular}

\begin{tabular}{lc}
\multicolumn{2}{c}{ Final Actinide Concentration } \\
\hline $\begin{array}{c}\text { Plutonium } \\
(\mathrm{g} / \mathrm{l})\end{array}$ & $\begin{array}{c}\text { Americium } \\
\mathrm{g} / \mathrm{g})\end{array}$ \\
\cline { 2 - 2 } $2.6 \times 10^{-7}$ & $1.8 \times 10^{-10}$ \\
$1.1 \times 10^{-7}$ & $1.5 \times 10^{-10}$ \\
$1.2 \times 10^{-7}$ & $1.2 \times 10^{-10}$ \\
$7.4 \times 10^{-8}$ & $7.3 \times 10^{-11}$ \\
$6.4 \times 10^{-8}$ & $7.0 \times 10^{-11}$ \\
$3.3 \times 10^{-8}$ & $2.5 \times 10^{-11}$ \\
$2.3 \times 10^{-8}$ & $2.0 \times 10^{-11}$
\end{tabular}

a. Equilibrated with $6.5 \mathrm{mmol}$ sodium hydroxide in process water ( $\mathrm{pH} 12.7)$

b. Initial plutonium concentration: $1.0 \times 10^{-4} \mathrm{~g} / \mathrm{Q}(\mathrm{pH} 12.0)$

c. Initial americium concentration: $1.4 \times 10^{-6} \mathrm{~g} / \mathrm{Q}(\mathrm{pH} 12.0)$ 


\section{REFERENCES}

1. T. E. Boyd, R. L. Kochen, and M. Y Price, "Removal of Radioactive Materials From Waste Solutions Via Magnetic Ferrites," Proc. ANS Topical Meeting on the Treatment and Handling of Radioactive Waste, Battelle Press, Columbus, OH, 1982.

2. T. E. Boyd and R. L. Kochen, Ferrite Treatment of Actinide Waste Solutions: Continuous Processing of Rocky Flats Process Waste, RFP-3476, Rockwell International, Rocky Flats Plant, Golden, CO, March 18, 1983.

3. T. E. Boyd and R. L. Kochen, "Actinide Removal From Waste Solutions by Ferrite Treatment," Waste Management 1983, Univ. of Arizona Board of Regents, Tucson, AZ, 1983.

4. T. E. Boyd and R. L. Kochen, Ferrite Treatment of Actinide Waste Solutions:
Multi-Stage Continuous Processing, RFP-3582, Rockwell International, Rocky Flats Plant, Golden, CO, January 27, 1984.

5. T. E. Boyd, R. L. Kochen, and M. Y. Price, Ferrite Treatment of Actinide Waste Solutions. Alternative Methods of Ferrite Production for Use in Waste Treatment, RFP-3692, Rockwell International, Rocky Flats Plant, Golden, CO, January 16, 1985.

6. L. O. Kolarik, "Colour and Turbidity Removal With Reusable Magnetite Particles-IV. Alkali Activated Magnetite - A New Solid, Reusable Coagulant-Adsorbent," Water Res., 17, pp 141147, 1983.

7. T. E. Boyd, M. J. Cusick, and J. D. Navratil, "Ferrite Separation Science and Technology," Recent Developments in Separation Science, 8 , pp 207-232, N. N. Li and J. D. Navratil, Eds., CRC Press, 1986. 
RFP-4100
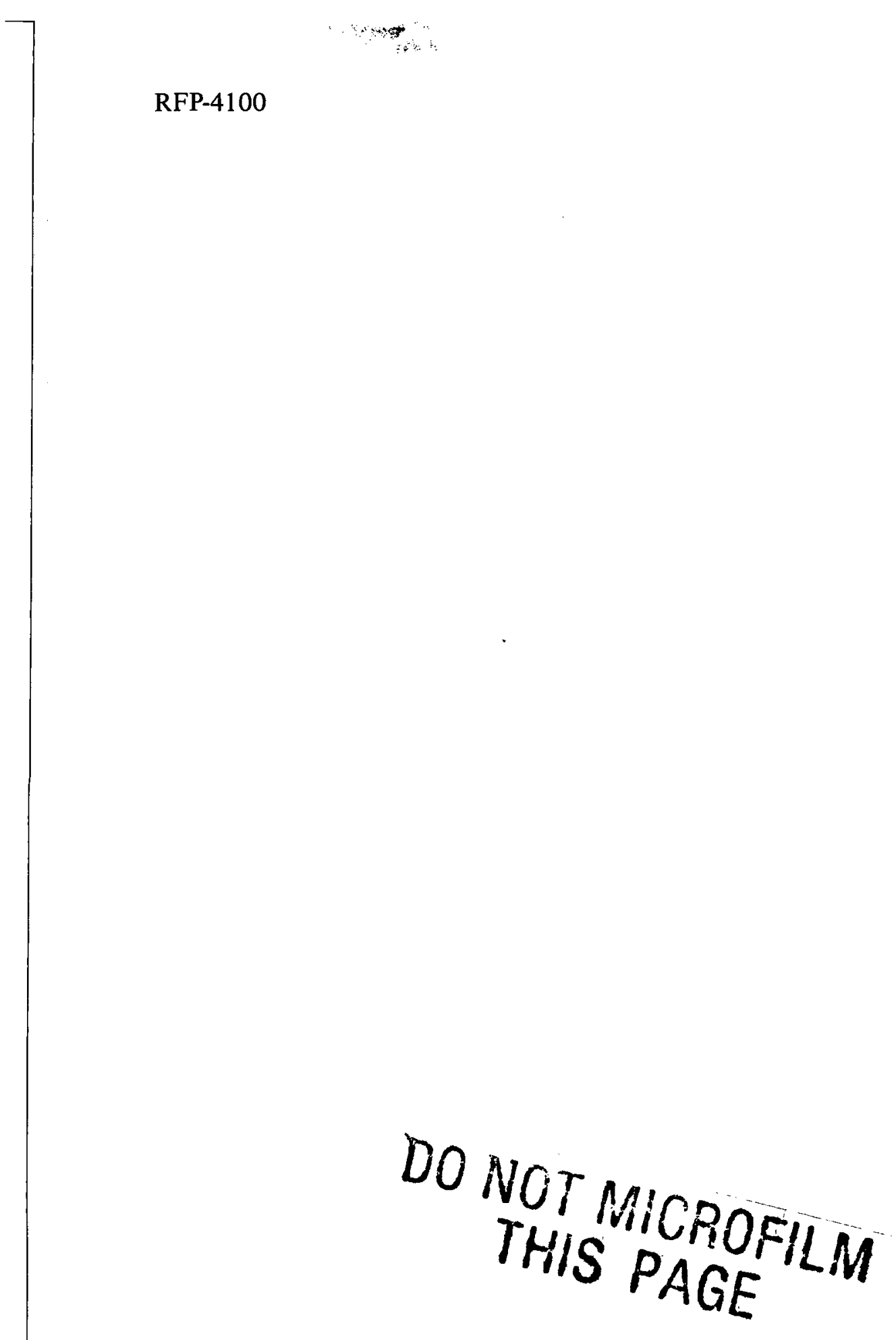